\title{
RELATIONSHIPSHIP BETWEEN THE POPULATION AGING AND THE SUPPLY OF SERVICES IN DIFFERENT REGIONS IN LITHUANIA
}

\author{
Daiva Labanauskaité1, Laura Astrauskaité2 ${ }^{2}$, Deimena KiyaK ${ }^{3}$ \\ Klaipèda University (Lithuania)
}

\begin{abstract}
An aging population is defined in the scientific literature as changes in the structural age composition of the population, which leads to growth in the population of those who are 60 years and older. The aging of population is a social and economic problem that needs to be understood and addressed. Aging of the population has a significant impact on national economies, as well as within individual regions of the country. The old age index has a significant impact on regional supply of services. It is worth stressing that in order to improve a community's quality of life and reduce disparities between regions, it is necessary to continually assess the level of development and regional development opportunities. Evaluation of the regional socio-economic situation should be performed periodically, so that regional policy measures can be directed to the areas of greatest need.

KEY WORDS: population aging, regional development, supply of services.
\end{abstract}

JEL CODES: R11, R12

\section{Introduction}

An aging population is one of the most relevant phenomena that have caused a lot of problems in recent years. The aging of population has had a significant impact on national economies, particularly the growth of the economic recession: the growing number of retired older people increases the cost of their maintenance, while the well-employed people have to indirectly maintain these retired people more and more. There is no doubt that the aging of society has an influence in many different ways, not only on individual countries, but also on each country's different regions.

The problem of the research: the aging of a population and its impact for regional development in Lithuania has not been widely researched. P. Dicken (2007) analyzed the changes of society's structure in the global economy. A. Ignasiak-Szulc, W. Kosiedowski (2007) discussed the state's role in the solution of problems caused by population aging in the research "Meaning of the Cohesion Policy of European Union in the development of countries and regions of Central and Eastern Europe". V. Podvezko and R. Ginevičius (2007) analyzed the changes in the Evaluating of economic and social development of Lithuanian counties by multiple criteria methods.

1 Daiva Labanauskaite - Klaipėda University, Social Science Faculty, Department of Economics, associate professor, social sciences, economy. Scientific interests: economics, marketing, turism

E-mail: daiva_labanauskaite@yahoo.com

Tel.: +37068642862.

2 Laura Astrauskaite - Klaipèda University, Social Science Faculty, Department of Economics, master student. Scientific interests: economics, marketing.

3 Deimena Kiyak - Klaipeda University, Social Science Faculty, Department of Economics, associate professor. Scientific interests: finance, accounting, pricing, financial and economic analysis.

E-mail: deimena@balticum-tv.lt

Tel.: +37068220253. 
T. Medaiskis, B. Gruževskis and S. Mikulionienè (2007) analyzed the aging process and its consequences for Lithuania, especially for the labor market in the research "The effects of an aging population on the labor market and enterprises: Trends and Challenges". This study was carried out without a separate research of each individual region in Lithuania, so it did not compare which regions have the most rapidly aging societies, and what had the biggest impact. Meanwhile, the aging of society is changing its social power and increasing the demand for health and social services. This trend means that the health insurance and other social security institutions will have higher costs, which in turn creates conditions that require the need to revise and adapt to these new needs for public resources in the areas of the economy (the possibility to participate in the labor market, plus income and savings rates), politics (power in political and public organizations), social security (social security), health (meeting the requirements for service development) and human ecology (meeting the needs of housing, the environment, village infrastructure, transport and so on).

The object of the research: the relationship between the aging population and the supply of services in Lithuanian regions.

The aim of the research: to analyze the relationship between the aging population and the supply of services in Lithuanian regions.

The tasks of the research:

- to define the concept of aging;

- to determine the factors that have contributed to the aging of the population;

- to analyze the relationship between the aging population and the supply of services within Lithuania;

- to make a forecast of changes in society aging and service supply in Lithuanian regions.

Methods of the research: the article has been prepared by structuring and generalizing the content of studies carried out by different authors and scholars, by analysis of documents to codify a synthesis of descriptive statistical methods, time series analysis, correlationship analysis, and the conclusions arising from the generation thereof.

\section{The concept of aging and its causes}

The aging of population is one of major processes occurring in Europe. The aging of population has a profound impact on European economies, welfare and development, including prosperity and well-being, so it is necessary to gather and deepen the knowledge about how to promote older people's health and quality of life, and how to avoid the costly consequences of this process, which affect the entire population (Švedijos visuomenès sveikatos institutas, 2007). L. Kligyte (2008: 9) adds that the aging population is one of the most important problems of our century, which has a significant impact on our economy and social policy. The author (ibid.) argues that a person can treat his/her aging differently, because it depends on the individual's character and ability to continue an active, fulfilling style of life.

According to O. G. Rakauskienè (2006: 19), the current process of aging is becoming a problem. The progress in addressing the aging process has had medical breakthroughs and is the result of wealth increases, but it is also one of the major public concerns. The search for a balance of social benefits and taxes is one of priorities in the government's policy.

In this article, only one aspect of this problem will be analyzed - the influence of an aging population on the development of regions in Lithuania. In order to clarify the meaning of this phenomenon, it is necessary to understand the concept of aging value.

In particular, one should separate the two concepts - the old-age population and the aging population level (public). In essence, both cases refer to the same phenomenon, but the first term only refers to a temporal snapshot of the population age structure of the state, while the second term requires at least two points of time comparisons of measurements, it presents the dynamics of the phenomenon (Mikulioniené, 2002: 45).

The aging of society is understood as structural population changes; the increasing number of older people and their percentage of the total population (Čepinskis, Kanišiauskienė, 2009: 20). However, A. Jurgelè- 
nas, A. Juozulynas, M. Butikis and K. Greičiūtè (2007: 94) say that aging is a complex process, consisting of elderly people in their relationship with society and the trend of an increase in life expectancy. According to the authors (ibid.), aging is a social phenomenon, but in this article this phenomenon can be seen as a social, economic or marketing phenomenon.

From an economics point of view, the aging of the population can be explained as structural population changes with the increase in the retirement age and declining working-age population. As such, it has a negative impact on the social insurance budget, where the percentage of citizens making payments is decreasing while that percentage receiving allowances is increasing.

S. Mikulionienè (2002: 45) distinguishes four basic old-age population-level indices:

- the level of old age - ratio of old people to the population;

- the average age of the population;

- age of the population - sex pyramid;

- the index age - old and young population ratio.

The author (ibid.) highlights that in order to find the pace of population aging, it is sufficient to perform any of the above age-level indices for measuring at least two different time points or a relatively older population and the population growth over a period of time. An increasing value of the indicator suggests that the present society is facing or will soon face the process of aging. Of course, it is necessary to accurately define the age increase in the number of people regarded as an aging population. Various sources identify the concept of an elderly man in different ways. V. Kanopiene and S. Mikulionienè (2006: 189) argue that an old age limit is negotiable, and is selected depending on the purpose of analysis. The most common are:

- The United Nations (UN) recommendation - 60 years old and older people;

- World Health Organization (WHO) recommendation - 65 years old and older people.

It is important to note the demographics of a society considered as being old, which is one-fifth of elderly people to a quarter (20 to 25 percent.) of the population.

In conclusion, it should be emphasized that for people who have reached 60 or 65 years, the threshold of falling within the old category is conditional and based largely on economic factors such as those identified with the upper and lower limit of the working age.

No phenomenon happens for no reason - no exceptions, including aging. J. Bagdanavičius (2008: 168) considers that the population age structure is related to the basic demographic processes - fertility, mortality, family formation and composition.

A group of authors (Medaiskis, Gruževskis, Mikulionienè, 2007: 243) have distinguished two basic determinants of aging:

- the expected increase in life expectancy;

- the decline in fertility.

Recently, an increasing number of researchers have drawn attention to another important factor leading to the aging of a population - emigration. Emigration accelerates aging. This is especially important for smaller nations such as Lithuania (younger compatriots dispersed throughout the world, resulting in a substantial change in the relative composition of the population in Lithuania). Of course, immigration has the opposite meaning: it slows the aging of a population, since immigrants are generally younger and have more children (Balsevičienè, 2008: 37).

S. Mikulionienè (2002: 48), in discussing the causes of aging, emphasizes that the greatest influence on this phenomenon is seen with a decline in fertility and mortality, while with the other two factors - migration and population age structure, their effects on an aging population are characterized by a relatively modest and short period of time. It is worth highlighting that the author does not mention their effects on life expectancy and aging, but instead, the language of the previous century on the population structure in play at that time. The author (ibid.) argues that the earlier age structure affects the formation of the demographic impact caused by the waves of migration 
It is interesting that in Lithuania, this aging has mainly been due to a significant decline in the birth rate and the emigration of the younger population (Grabauskas, Gaižauskienè et al., 2007: 10). In accordance with the information provided, it can be said that the main factors affecting the aging of population are the demographics of mortality, declining birth rates and emigration. Of course, there has been some influence by scientific and technological achievements in the fields of health and medicine.

\section{Aging effects on the country and its regions}

The aging of a society is a complex phenomenon, which leads to various social and economic impacts for each region, no matter what size it is. R. Suzmanas from the National Institute of Gerontology says that aging affects every country in every part of the world. Although there are important differences between developed and developing countries, global aging changes the social and economic nature of the planet and provides a serious challenge (Pasaulis sparčiai sensta, 2009: 3). S. Mikulionienè (2002: 49) points out that demographers first drew attention to the implications of aging. It is agreed that in scale and irreversibility, it changes the demographics of a society and the social structure of production, distribution and consumption systems, and also has an impact on practically all the social groups and layers of social interaction.

According to the authors (Čepinskis, Kanišauskienè, 2009: 29) aging affects different sectors of society, therefore, this must be taken into account when addressing the need to create old-age policies, setting targets and creating measures for this area:

- Social impacts of the concept of old age and aging, performance status of old people, relationships between generations, households and families including their formation / break-up cycles, income, savings, consumption and distribution, education, village infrastructure, housing requirements, and the requirements for the pension system.

- Economic impact areas of social protection, the labor market and employment, and health care.

Of course, the impact areas are closely related and mutually influence each other. It should be emphasized that the impacts that the authors identified of the aging process are not the only ones, and this model could still be complemented by other ones that authors have mentioned in the impact areas.

L. Žalimiene (2002: 247) argues that with old age and social risk factors giving rise to the need for social protection, that social protection policies need to ensure income and compensation for withdrawing from the labor market due to old age, as well as the specific services needed for personal and social needs (housing, home help, transport facilities, etc.).

Lithuania, like the other EU Member States, has an increasing proportion of elderly each year, 60 years of age and older people (Lietuvos apskritys, 2008: 4). All of this means that a decreasing proportion of working age people will be able to withdraw to retirement. If the number of people who cease to work exceeds the number of those entering the work market, a shortage of skilled workers will emerge (the Swedish National Institute of Public Health, 2007). For this reason, many European countries are faced with the challenge of financing a pension system for an aging and shrinking labor force.

Other authors (Jurgelènas, Juozulynas, Butikis, Greičiūtè, 2007: 92) identify one more problematic character of an aging population: an aging society is changing in its social power, with its increasing demand for health and social services. This feature means that the health insurance and other social security institutions will have higher costs because chronic heart disease and cancer remain the leading causes of death, particularly among older people. This will lead to huge costs for health systems.

S. Mikulioniene (2002: 50) says that the number of older people is forcing an increase in time to review and adapt to the new needs of public resources in areas such as the economy (the possibility to participate in the labor market, plus income and savings rates), politics (power in political and public organizations), social security (social security), health (meeting the needs of service development) and human ecology (meeting the needs of housing, the environment, village infrastructure, transport and so on). 
With this point of view, and according to a group of authors (Medaiskis, Gruževskis, Mikulionienè, 2007: 249), it may be argued that in an aging society facing labor, consumption and investment savings through structural change, there will be new requirements for the pension system, the need to develop and optimize the social services system, to modernize health care, and for older people take part in their own spiritual and psychological welfare.

An aging population will increase pension and health care spending, and this will increase public expenditures. In 2006, the European Commission announced that the member states will greatly increase spending on pensions, health care and long-term care, and that this will slow gross domestic product (GDP) growth. If policies remain unchanged, the potential of the European Union's economic growth rate will decrease by half by 2030 (Pasaulis sparčiai sensta, 2009). It is worthwhile to emphasize that the increase in public spending is leading to a higher cost level in different regions, and that slowing the country's GDP growth is leading to a slowing regional GDP growth.

The ruling of the National Science program "Social challenges to national security" funded by the Research Council of Lithuania (Lietuvos Respublikos Vyriausybè, 2009) briefly and clearly states that the aging population increases the strain on the social security system and puts new demands on the labor market and labor resources, including personnel management. The older (60 years old and over) population has more impact on the functioning of society, but this factor was underestimated for the work environment and the public.

Summing up the analyses of the scientific literature, it's noted that most authors argue that the aging of society has the greatest influence on the labor market and the regional budget expenditures: with the increasing number of people who need to be paid pensions and other benefits increasing the state budget expenditures. Another area that may be affected by the increasing number of older people is the need to expand social services. The aging population has a strong influence on the tax system and to the country's economic performance. It should be noted that with the aging of society, one of the main challenges is the need to provide a comprehensive solution to the problems arising.

\section{Statistical relationship between indices of resident aging and service sector}

In order to find out the influence of a growing total number and a part between all 60 year old and older residents on the economic entities (especially in the field of services) operating in Lithuanian districts, a correlationship analysis was carried out and a method of a total of places of multicriteria assessment was applied, both of which reveal the interrelationship between indices of old age and the number of service companies operating in the regions, as well as assess in which districts the influence of society aging is the biggest. The possible trends of old age level and the number of economic entities operating in districts in the future are provided while applying regression analysis.

Aging of society has distinct consequences on economic and social system of every country and region. One of the ways to assess the influence of this process on the distribution of service companies in Lithuanian districts - is to carry out a correlationship analysis, which assesses interrelationship between the two phenomena. Author (Stumbrys, 2006: 14) emphasizes, that the method of correlationship analysis measures the strength of relationship only quantitatively and doesn't determine their reasons.

According to the performed calculations, the obtained results (see table 1) show, that there is a strong or a very strong direct relationship between the level of aging and the number of companies supplying electricity, gas and water in Lithuanian regions, only in Marijampolè district the interface between these indices is average. It is interesting that the same correlationship meanings link the level of aging with business entities engaged in real estate, rent and other business activity, i.e. the relationshipship in all regions is direct strong or very strong and in Marijampolè - average.

It should be emphasized that a relationship between level of old age and the number of business entities operating in construction field is direct in all districts, and the level of unity slightly fluctuates, i.e. from average in Marijampolé, Šiauliai, Taurage and Utena districts to strong in the rest regions. The same meanings of correlationship coefficient are between level of old age and the subjects of post and telecommunication: a direct strong or average relationship predominates. 
Table 1. Correlationship coefficient between the number of service companies and the level of old age

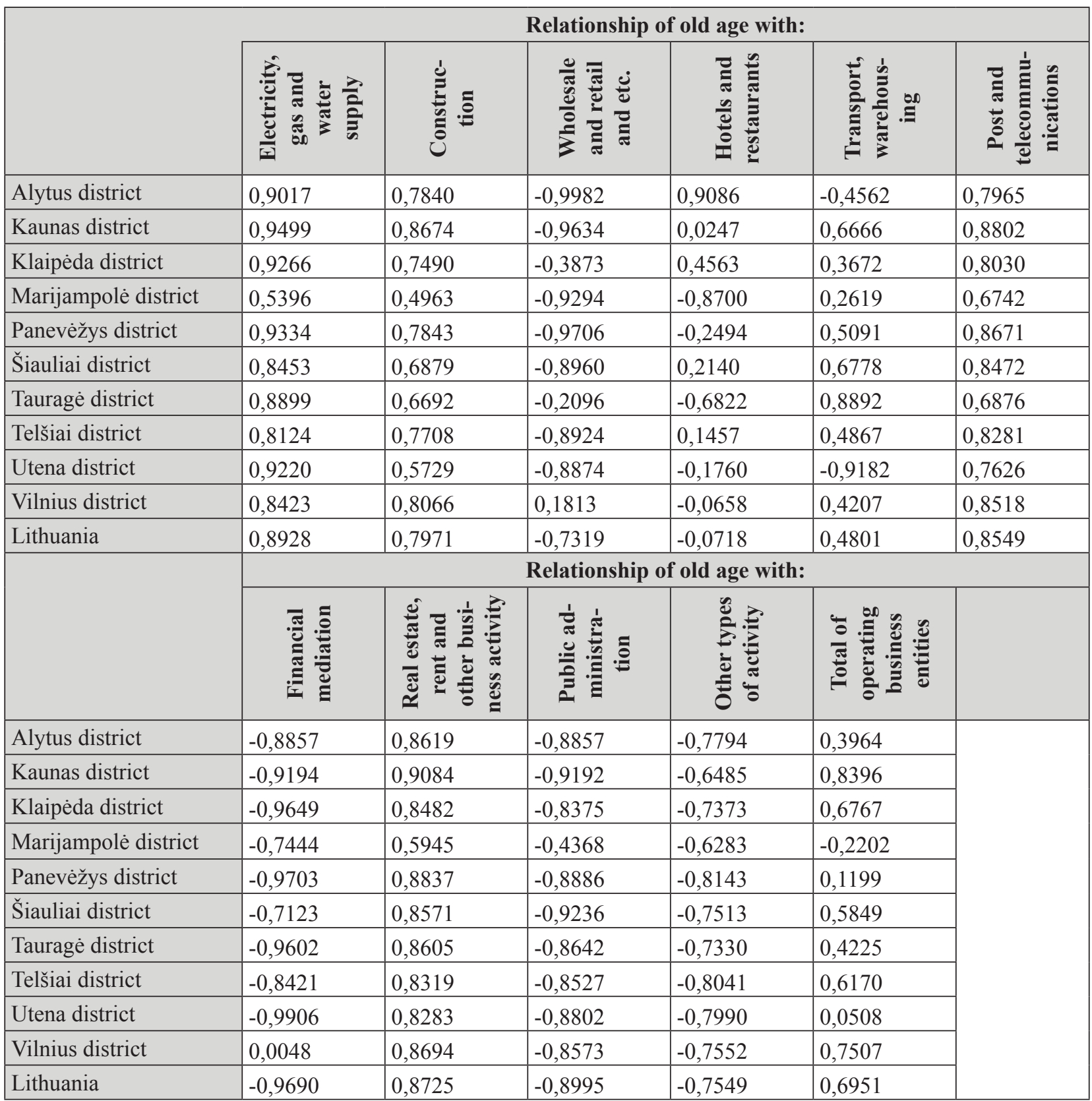

While analyzing data (see table 1) it is noticeable, that the number of business entities in wholesale and retail trade, financial mediation, public administration and other type of activity is related to the level of aging in a negative, i.e. reverse relationship. Relationship of unity between these indices is also similar: it fluctuates everywhere from strong to very strong, only the relationship between the level of old age and business entities of other type of activity is slightly weaker, i.e. strong or average. However, several exceptions are noticeable: there is a direct very weak relationship between the level of aging and the number of financial mediation companies in Vilnius district; correlationship relationship unity is weak between the level of old age and retail and wholesale trade in Klaipeda and Taurage districts, and in Vilnius district not only the strength of unity is different, but direction as well - here the relationship is very weak and direct.

According to the data provided above (see table 1) it can be seen that there is no equal relationship between the level of old age and the number of business entities of hotels and restaurants, transport and warehousing. The relationship between these indices fluctuates from very weak to very strong, from direct 
to reverse. It is worth noticing that all districts (except Marijampolè) have a direct relationship between the level of old age and the total number of business entities operating in the district. However the unity of relationship is different: these indices in Kaunas and Vilnius districts have a strong unity, in Klaipeda, Šiauliai, Taurage and Telšiai districts - average, in Alytus and Marijampolè - weak, Panevėžys and Utena - very weak. Summarizing the results of relationships of this group indices a conclusion can be made that the aging society (according to the level of old age) has a different influence on the distribution of service companies in separate regions.

It is worth emphasizing that the level of reliability of most above mentioned correlation coefficients is lower than 5 per cent. Reliability which is higher than 70 per cent is: in Vilnius district determining the relationship between the level of old age and the number of business entities in financial mediation, in Kaunas, Telšiai and Vilnius district and generally in Lithuania - between the level of old age and the number of hotels and restaurants, in Panevezžys and Utena districts when correlation is calculated between the level of old age and the created value of GDP, and Marijampole district - between the level of old age and the total number of operating business entities. It should be emphasized that correlation link between the previously mentioned index groups is weak or very weak therefore reliability coefficient is high, i.e. the obtained correlation link is unreliable. Nevertheless, there is a noticeable trend that mostly reliability is low, therefore correlation link is reliable.

\section{Assessment of the influence of aging on the distribution of service companies}

Having found, that the aging society is quite closely related to the distribution of service companies in Lithuanian regions, it is important to assess in which field the influence of aging is the highest. A method of the total of places of multicriteria assessment helps to carry out this assessment, which according to all correlation meanings helps to rank Lithuanian districts based on the size of the aging influence starting with the region where the influence is the biggest and to the region where the influence of society aging is the smallest. It should be emphasized, that while assigning one or another place to each region, the trend of relationship (direct or indirect relationship) is not taken into account because it is not very important. While dividing Lithuanian districts according to the size of the impact of aging, the most important is the strength of correlation coefficient.

The table 2 below gives places of districts according to the meanings of correlation coefficient among the number of service companies and the level of aging as well as index of old age. Seeking general results while using the same method of total of places, the obtained results are connected into one final ranking of districts where in the first place is a district, where society aging has the strongest influence and in the tenth - the one having the weakest.

According to the provided data (see table 2) it can be seen, that according to the correlation coefficient, which was calculated between the level of aging and the number of service companies which operated in the districts, the aging society has the strongest influence in Panevėžys district and the smallest - in that of Marijampolè. According to correlation, which was calculated between the index of old age and the number of service companies, which operated in the districts, Kaunas district appears in the first place and Vilnius - in the last place. It is necessary to emphasize that according to different indices of aging, the places taken by districts are quite similar. The biggest difference of places is that of Marijampole district: according to the level of aging Marijampole district is in the tenth place and according to the index of old age - in the second. The difference of places taken by other districts in accordance with different indices of aging are only places from 2 to 4. 
Table 2. Places of Lithuanian districts based on the method of multicriteria assessment of the total of places

\begin{tabular}{|l|l|l|l|}
\hline & $\begin{array}{c}\text { According to the level of } \\
\text { aging }\end{array}$ & $\begin{array}{c}\text { According to the index of } \\
\text { old age }\end{array}$ & Total \\
\hline Alytus district & 3 & $4-6$ & 3 \\
\hline Kaunas district & 2 & 1 & 1 \\
\hline Klaipedda district & 6 & 3 & $4-5$ \\
\hline Marijampolè district & 10 & 2 & 6 \\
\hline Panevėžys district & 1 & $4-6$ & 2 \\
\hline Šiauliai district & 4 & $4-6$ & $4-5$ \\
\hline Tauragė district & 7 & 9 & 8 \\
\hline Telšiai district & 9 & $7-8$ & 9 \\
\hline Utena district & 5 & $7-8$ & 7 \\
\hline Vilnius district & 8 & 10 & 10 \\
\hline
\end{tabular}

The final places of Lithuanian districts according to the assessment of the influence of society aging on the distribution of service companies in regions are provided above (see table 2). Having combined all calculations it was obtained that: Kaunas district is in the first place and that of Vilnius - in the tenth. It is worth emphasizing that the first places are taken by the districts which are in the central part of the country, districts of eastern Lithuania are at the bottom of the list, and the districts of the western part are in the middle. It should be stressed that there is no relationship between the place occupied and whether there is one of the cities of Lithuania in that district, e.g. Vilnius district takes only the tenth place, though the country's capital belongs to the district, however Kaunas district with the second biggest Lithuanian city (Kaunas) takes the first place. Nevertheless we can see a small relationship between the place taken and the level of aging, because districts, where the level of aging is low, take the last places, and those where the level of aging is high - the first places.

While summarizing the obtained results we can state that the strength of influence of society aging on region partly depends on the level of aging, which is in that region. For this reason it should be emphasized that in those regions where the level of aging is extremely big, businessmen (or their marketers) should pay a lot of attention to the satisfaction of the needs of persons over 60 years old.

5. The trends of a change of aging process and the number of operating business entities in the future

While forecasting the level of aging (see picture 6), determination coefficient equals 75.8 percent, i.e. the model sufficiently describes the event, though doing bigger research it is recommended to revise the model. Trends of the level of aging are equivalent, but they are not good: presently still "young" districts will soon surpass the $20 \%$ limit. The level of aging in Klaipeda district already in 2012 will be 20.07 percent, and Vilnius and Telšiai districts will cross the limit of "an old" society in 2020 and will reach the level of aging respectively 21.02 percent and 20.92 percent. Nevertheless, Klaipeda, Telšiai and Vilnius districts will remain the youngest and the oldest societies will continue to be in Alytus, Panevėžys and Utena districts. It is forecasted that in 2020 the level of aging in Alytus and Utena districts will exceed the limit of 25 percent and will respectively be 25.18 percent and 25.59 percent.

Having reviewed the forecasted trends of the level of society aging and old age coefficient, it was noticed that this negative phenomenon of a society will also take place in the future and its pace will not be slow. For this reason it is necessary to find out how will the number of business entities operating in Lithuanian districts change with the aging of society.

It is worth emphasizing that though in 2010 if compared to 2009 the number of operating business entities decreased in all districts, according to forecasts (see table 3) in 2011, 2012 and 2020 the number of operating 
business entities will increase in all regions. It should be stressed that every year the number of business entities will increase only slightly, but in ten years time the total number of business entities operating all over Lithuania should increase by even 30 percent., similar trends are noticeable in separate regions as well. While forecasting, a determination coefficient was calculated and its obtained meaning equals 69.6 percent, therefore it can be stated that regression equation for forecasts is reliable.

Table 3. The number of business entities operating in Lithuania and its regions in 2009-2020 m.

\begin{tabular}{|l|l|l|l|l|l|}
\hline & \multicolumn{1}{|c|}{$\mathbf{2 0 0 9}$} & \multicolumn{1}{c|}{$\mathbf{2 0 1 0}$} & \multicolumn{1}{c|}{$\mathbf{2 0 1 1}^{*}$} & \multicolumn{1}{c|}{$\mathbf{2 0 1 2}^{*}$} & \multicolumn{1}{c|}{ 2020* } \\
\hline Alytus district & 3234 & 3130 & 3247 & 3291 & 3643 \\
\hline Kaunas district & 16989 & 16846 & 17565 & 18024 & 21693 \\
\hline Klaipéda district & 10403 & 10254 & 10803 & 11128 & 13732 \\
\hline Marijampolè district & 3004 & 2964 & 3014 & 3034 & 3192 \\
\hline Panevėžys district & 6227 & 5952 & 6105 & 6127 & 6299 \\
\hline Šiauliai district & 6825 & 6665 & 6898 & 7010 & 7904 \\
\hline Tauragė district & 2037 & 1973 & 2060 & 2097 & 2396 \\
\hline Telšiai district & 3312 & 3260 & 3397 & 3473 & 4088 \\
\hline Utena district & 2873 & 2811 & 2871 & 2891 & 3047 \\
\hline Vilnius district & 29670 & 29347 & 31273 & 32483 & 42169 \\
\hline Lithuania & 84574 & 83202 & 87231 & 89557 & 108161 \\
\hline
\end{tabular}

Summarizing the forecasts of the indices of regions it should be emphasized that the growing coefficient of old age and the level of aging can strongly influence the number of business entities operating in districts. Of course, it cannot be forgotten that the number of business entities is influenced not only by aging society, but also by other criteria, which can distort the forecasts obtained in this work.

Having carried out correlation analysis the data obtained revealed that aging of residents is closely related to the number of service companies operating in Lithuanian districts. While performing calculations with both indices of aging, an average, strong or very strong relationship predominates in all districts. While performing calculations with indices of both the level of aging and the index of old age, the results are obtained that a reverse relationship connects these indices with the number of the type of companies of wholesale and retail trade, financial mediation, public administration and other activity. The number of the companies of other activities is directly influenced by the aging of society, therefore with the growth in the number of people of old age, the number of companies of these activities should grow.

The calculations of the method of the amount of places of multicriteria assessment has revealed, that the aging society has the strongest influence on the distribution of service companies in Kaunas, Panevėžys and Alytus districts, and the smallest influence of the analyzed process is in Vilnius, Telšiai and Taurage districts.

Regression analysis has revealed pessimistic forecasts: the number of 60 year olds and older persons will grow markedly in the future, which has a negative influence on the country and on every region separately. A positive forecast is only for the number of jointly operating business entities, because the forecasts show that the number of companies should grow in the future. The growing number of companies means more workplaces, better living conditions and other positive economic processes.

\section{Conclusions}

1. The aging of society is the changes of the structure of inhabitants which determines the increase of 60 years and older people. The aging of society is both social and economical problem and it is necessary to understand and solve it. Misunderstanding or wrong understanding of a problem may be one of the reasons why nation (and regions) experience negative consequences. 
2. The aging of society determines many factors. A birthrate and mortality, growing number of elder people and their part in a total population, emigration, the growing relationship between old people and children under 15-year-old are the main factors.

3. Having assessed the influence of the aging of society on the economics of Lithuanian regions according to two indices of aging - level of old age and index (coefficient) of old age - it was noticed:

- The relationship of the level of old age with indices of service companies is quite various. The strength of relationship fluctuates very strongly though mostly closeness of relationship is strong or very strong. Also it is revealed that the strongest relationship of this index of most Lithuanian regions is with the number of operating electricity, gas and water supply as well as financial mediation companies. It is important to emphasize that the level of old age and the number of wholesale and retail trade, financial mediation, public administration companies and those of other types of activity is joined by an adverse relationship.

- The relationship of the coefficient of old age with the number of operating business entities based on a district - is quite similar to the relationship of the level of old age with the analyzed indices. Index (coefficient) of old age has a considerable influence on the number of service companies in all regions. The weakest relationship is between the coefficient of old age and the number of hotels and restaurants. It is important to emphasize that index of old age is reversely related to the same groups of service companies as the level of old age.

3. The method of the total of places of a multicriteria assessment has revealed that the aging society has the biggest influence in Kaunas district and the least - in Vilnius district. The obtained results showed that there is a relationship between the level of aging and the influence of society aging: the higher the level of aging in a region, the bigger influence on the business activity of that region the aging society has.

4. Results of regression analysis have shown that aging of society in both Lithuania and in separate districts will take place in the future (at least the next 10 years) as well. In the near future the districts which haven't yet reached the limit of "an old" society, will cross it, i.e. the level of aging will exceed the limit of 20 percent in all districts. Contrary to the indices of society aging, forecasts for the number of operating business entities are positive. Based on the results of regression equation it is noticeable, that the number of companies operating in all districts and generally in all Lithuania will only grow in the future. For this reason in the future, businessmen (or persons working in business field) before taking new activities or continuing the already started ones, have to assess the changing needs of a changing society: the process of aging influences such fields as requirements for housing, settlement infrastructure, distribution and usage of income and savings, health security and etc. In front of the structure of a changing society when the number of old people increases there must be an inevitable change in the availability, uniqueness of the supplied services, methods of supplying and other actions of marketing.

\section{References}

Bagdanavičius, J. (2008). Regioniniai gyvenimo kokybės ir gyventojų kokybės skirtumai. Ekonominès ir socialinès studijos. Visuomenès darni plètra: problemos ir perspektyvos. Moksliniu straipsniu rinkinys (V). Vilnius: Vilniaus pedagoginio universiteto leidykla, p. 165-178.

Balsevičienè, I. (2008). Vyresniosios ir jaunesniosios kartos santykiu itampos laukas bei jo mažinimas švietimo veikla [interaktyvus]. Vilniaus pedagoginis universitetas. Prieiga internetu: http://vddb.laba.lt/fedora/get/LT-eLABa0001:E.02 2008 D_20080924_180854-41519/DS.005.0.02.ETD [žiūreta 2010-02-22].

Čepinskis, J., Kanišiauskienè, V. (2009). Visuomenès senėjimo iššūkių valdymo prielaidos. Organizaciju vadyba: sisteminiai tyrimai, Nr. 49, p. 19-35. Kaunas: Vytauto Didžiojo universiteto leidykla.

Dicken, P. (2003). Global shift: reshaping the global economic map in the 21st century. London: SAGE Publications.

Grabauskas, V., Gaižauskienè, A. ir kt. (2007). Lietuvos gyventoju sveikatos rodikliai ir ju pokyčiu raida [interaktyvus]. Vilnius. Prieiga internetu: <http://www3.Irs.lt/owa-bin/owarepl/inter/owa/U0165514.pdf> [žiūrèta 2010-02-22]. 
Ignasiak-Szulc, A., Kosiedowski, W. (2007). The meaning of cohesion policy of European Union in the development of countries and regions of central and Eastern Europe. The recent development of the EU: challenges and experience. The 3rd scientific volume, p. 79-87. Klaipèda.

Jurgelėnas, A., Juozulynas, A., Butikis, M., Greičiūtė, K. (2007). Senejjimas ir gyvenimo kokybé. Gerontologija [interaktyvus]. Prieiga internetu: <http://www.gerontologija.lt/files/edit_files//File/pdf/2007/nr_2/2007_92_96.pdf> [žiūrèta 2010-02-22].

Kanopienė, V., Mikulionienè, S. (2006). Gyventojų senėjimas ir jo iššūkiai sveikatos apsaugos sistemai. Gerontologija, Nr. 7 (4), p. 188-200. Vilnius: Lietuvos gerontologų ir geriatrų draugija.

Kligytė, L. (2008). Senų ir pagyvenusių asmenų socialinių ryšių kaita: senelių vaidmenys [interaktyvus]. Vilnius: Mykolo Romerio universitetas Prieiga internetu: <http://vddb.library.lt/fedora/get/LT-eLABa-0001:E.02 2009 〜D_20090129_153956-54529/DS.005.0.02.ETD> [žiūrèta 2010-02-22].

Lietuvos apskritys 2008. (2009). Statistikos departamentas prie Lietuvos Respublikos Vyriausybès [interaktyvus]. Vilnius. Prieiga internetu: http://www.stat.gov.lt/lt/catalog/pages_list/?id=1112 [žiūrèta 2012-02-23].

Lietuvos Respublikos Vyriausybè. (2009). Nutarimas Dèl Nacionalinès mokslo programos , Socialiniai iššūkiai nacionaliniam saugumui “patvirtinimo, Nr. 1424. Vilnius.

Medaiskis, T., Gruževskis, B., Mikulionienè, S. (2007). Visuomenès senėjimo padariniai darbo rinkai ir įmonėms: tendencijos ir iššūkiai. Lietuvos ekonomika Europoje ir globalioje erdveje. Straipsnių rinkinys. Vilnius: VšI „Ekonominių tyrimų centras“, p. 241-266.

Mikulionienè, S. (2002). Senejjimo demografija. Socialinè gerontologija: ištakos ir perspektyvos. Kaunas: Vytauto Didžiojo universiteto leidykla, p. 42-60.

Pareigis, R., Dorofejeva, O. (2004). Lietuvos nacionalinė regioninė politika ir jos igyvendinimo prielaidos. Ekonomika, Nr. 67 (2), p. 61-72. Vilniaus universiteto leidykla.

Pasaulis sparčiai sensta. (2009). Lietuvos žinios. [interaktyvus]. Vilnius. Prieiga internetu: <http://www.delfi.lt/news/ daily/world/article.php?id=23197683> [žiūrèta 2010-02-22].

Podvezko, V., Ginevičius, R. (2009). Evaluating the changes in economic and social development of Lithuanian counties by multiple criteria methods. Technological and Economic Development of Economy, No. 15 (3), p. $418-436$. Vilniaus Gedimino technikos universiteto leidykla.

Rakauskienė, O. G. (2006). Valstybès ekonomine politika. Vilnius: Mykolo Romerio universiteto Leidybos centras.

Stumbrys, D. (2006). Butu vertę Vilniuje įtakojančiu veiksniu statistiné analizė [interaktyvus]. Vilnius. Prieiga internetu: http://www.butastau.lt/gallery/paveiksleliai/statistine_analize/statistine_analize.pdf [žiūrèta 2012-04-05].

Švedijos nacionalinis visuomenès sveikatos institutas. (2007). Sveikas senejjimas Europos siekis. Sutrumpinta versija [interaktyvus]. Švedija. Prieiga internetu: $<$ http://www.healthyaging.nu/upload/Short\%20version/lithuanian_shortHA_web070712.pdf> [žiūrèta 2010-02-22].

Žalimienè, L. (2002). Socialinė politika ir pagyvenusių žmonių socialinè apsauga. Socialine gerontologija: ištakos ir perspektyvos. Kaunas: Vytauto Didžiojo universiteto leidykla, p. 240-257.

\title{
VISUOMENÉS SENËJMO IR PASLAUGŲ PASIŨLOS RYŠYS LIETUVOS REGIONUOSE
}

\author{
Daiva Labanauskaité, Laura Astrauskaité, Deimena KiYaK \\ Klaipedos universitetas (Lietuva)
}

\section{Santrauka}

Visuomenės senėjimas yra vienas aktualiausių reiškinių, pastaraisiais metais keliančių nemažai problemų. Didejjantis pagyvenusių žmonių skaičius veikia šalių ekonomiką, ypač augant ekonomikos recesijai: augantis senyvo amžiaus žmonių skaičius didina valstybių išlaidas jiems išlaikyti, dirbantys asmenys netiesiogiai turi išlaikyti vis daugiau į užtarnautą poilsį išèjusių žmonių. Neabejojama, kad visuomenės senèjimas skirtingai veikia ne tik konkrečias valstybes, bet ir kiekvienos šalies konkrečius regionus.

Tyrimo problema: mažai ištirtas visuomenès senėjimo procesas Lietuvos regionuose ir šio proceso ittaka regionams. T. Medaiskis, B. Gruževskis ir S. Mikulionienè 2007 metų tyrime „Visuomenès senėjimo padariniai darbo rinkai ir imonėms: tendencijos ir iššūkiai“ analizavo visuomenès senèjimo procesą ir pa- 
darinius visai Lietuvai, ypač darbo rinkai. Šis tyrimas atliktas netiriant atskirai kiekvieno Lietuvos regiono, todèl neleidžia palyginti, kuriuose regionuose visuomenès senėjimas vyksta sparčiausiai ir kur stebima didžiausia minèto proceso įtaka ekonominei raidai. Tuo tarpu senstant visuomenei, keičiasi jos socialinè galia, didejja sveikatos ir socialinių paslaugų poreikis. Tai reiškia, kad valstybių ligonių kasos ir kitos socialinio draudimo îstaigos turès daugiau išlaidų, tai savo ruožtu lems būtinybę peržiūrèti ir naujiems poreikiams pritaikyti visuomenės išteklius ekonomikos (galimybės dalyvauti darbo rinkoje, pajamų ir santaupų lygis), politikos (galia politinèse ir visuomeninėse organizacijose), socialinio saugumo (socialinės garantijos), sveikatos apsaugos (poreikius atitinkančių paslaugų plètra) ir žmogaus ekologijos (poreikius atitinkantys būstai, aplinka, gyvenvietès infrastruktūra, susisiekimas ir pan.) srityse.

Tyrimo objektas: visuomenès senėjimo įtaka Lietuvos regionų plètrai.

Tyrimo tikslas: išanalizuoti visuomenės senẻjimo įtaką Lietuvos regionams.

Tikslui pasiekti išsikelti šie uždaviniai:

- apibrèžti visuomenès senėjimo sampratą;

- nustatyti veiksnius, kurie lemia visuomenès senėjimą;

- nustatyti visuomenès senejjimo įtakos regionams sritis;

- išanalizuoti senstančios visuomenès įtaką Lietuvos regionų plètrai.

Atliekant visuomenės senėjimo poveikio regionų plètrai tyrimą taikyti mokslinès literatūros ir teisinių dokumentų analizès, sisteminès analizès, sintezès, aprašomosios statistikos metodai, laiko eilučių ir koreliacinè analizè.

Apibendrinus ịvairiu autorių nuomones, visuomenès senėjimas gali būti apibūdinamas kaip gyventoju struktūros pokyčiai, kurie lemia 60 metų ir vyresnių gyventojų skaičiaus augimą. Visuomenès senèjimas tiek socialinè, tiek ekonominè problema, kurią būtina suprasti ir spręsti. Nesupratimas ar blogas problemos supratimas gali būti viena priežasčiu, kodèl valstybè (ir regionai) patiria su regionų plètra susijusių sunkumų.

Visuomenès senëjimą lemia daugelis veiksnių. Pagrindiniai jų: gimstamumas ir mirtingumas, didejantis senyvo amžiaus žmonių skaičius ir jų dalis bendrame gyventojų skaičiuje, emigracija, senyvo amžiaus ir vaikų iki 15 metų santykio didejjimas. Senstanti visuomenẻ labiausiai veikia regionų biudžeto išlaidas, nes didina išlaidas socialinei apsaugai: pensijoms, sveikatos apsaugai ir pan. Mokslinès literatūros apžvalga atskleidè, kad visuomenės senėjimas nemažai įtakos turi darbo rinkai (užimtumui ir nedarbui), BVP ir regionų plètros rodikliams.

Visame pasaulyje vyrauja netolygumai tarp regionų. Akcentuotina, kad regionų skirtumai lemia ne tik nevienareikšmę sąvokos regionas prasmę, bet ir skirtingus regionų plètros, augimo bei vystymosi tempus. Regionu išsivystymas suprantamas kaip vientisas bendruomenès gyvenimo lygis socialiniu, ekonominiu, aplinkosaugos, sveikatos apsaugos, technologijos, kultūros ir rekreacijos aspektais tam tikroje teritorijoje tam tikru momentu.

Verta pabrèžti, kad siekiant gerinti bendruomenès gyvenimo kokybę ir mažinti skirtumus tarp regionų, būtina nuolat vertinti regionu išsivystymo lygi bei plètros galimybes. Regionų socialinè-ekonominè padėtis turètų būti vertinama periodiškai, kad regioninès politikos priemones būtų galima nukreipti į tuos regionus, kuriems jų labiausiai reikia. Periodiškai atliekamas esamos situacijos vertinimas leidžia kontroliuoti lěšas, kurios skiriamos regionų ekonominei ir kitų sričių darniai plètrai.

Regionų išsivystymo lygiui ar plètrai ịvertinti ịvairūs autoriai pateikia skirtingas metodikas, t. y. skirtingus rodiklių rinkinius. Reikia paminèti, kad nè vienoje regionų plètrą ir išsivystymą vertinančiu metodiku neišskiriami rodikliai / rodikliu grupé, pagal kurią būtu galima palyginti regionus visuomenès senéjimo aspektu, taip pat nesukurta metodika (rodiklių rinkinys), kurią pasitelkus būtų galima ịvertinti šio reiškinio poveikị regionams.

Ivertinus visuomenès senėjimo itaką Lietuvos regionų ekonomikai pagal du senejjimo rodiklius - senatvès lygị ir senatvès koeficientą - pastebèta: senatvès lygis su regionų ekonomikos rodikliais susijęs skirtingai, o senatvès koeficientas pagal apskritis ganètinai panašus. Senatvès indeksas (koeficientas) daro didelę itaką visų regionų užimtumo ir nedarbo lygiams, biudžetų pajamoms ir išlaidoms, silpnas ryšys yra tarp 
regionų sukuriamos BVP vertės, BVP, tenkančio vienam gyventojui, bei užimtujų skaičiaus. Taigi daroma išvada, kad demografinis gyventojų senėjimas didžiausią poveikį turi darbo rinkai ir apskričių biudžetams. Svarbu pabrěžti, kad senèjimo procesas atvirkščiai susijęs su užimtuju skaičiumi, užimtumo lygiu ir išlaidomis socialinei apsaugai, o su kitais analizuojamais rodikliais ryšys yra tiesioginis.

PAGRINDINIAI ŽODŽIAI: visuomenès senëjimas, regionu plètra, socialiniai ir ekonominiai visuomenès senëjimo padariniai.

JEL KODAI: R11, R12 